\title{
Are Sexual Minorities Hard-to-Survey? Insights from the 2020 Census Barriers, Attitudes, and Motivators Study (CBAMS) Survey
}

\author{
Nancy Bates ${ }^{1}$, Yazmín A. García Trejo ${ }^{1}$, and Monica Vines ${ }^{1}$
}

\begin{abstract}
As a stigmatized and vulnerable population, sexual minorities are often assumed to also be a hard-to-survey population. Despite this implicit assumption, there is little empirical evidence on the topic. Using a nationally representative survey that included sexual orientation (the Census Barriers, Attitudes, and Motivators Survey), we examine level of effort, the Census Bureau's Low Response Score (LRS), and stated intent to respond to the 2020 Census as proxy measures to explore this assumption. We found no evidence that sexual minorities required higher levels of effort to secure participation in the survey. Additionally, we found that compared to straight respondents, lesbians, gays, and bisexuals had a higher intent to respond to the 2020 Census. We surmise the current social climate in the United States may be a contributing factor to these findings.
\end{abstract}

Key words: SOGI; LGBT; hard-to-count; HTC.

\section{Introduction}

As survey and census nonresponse continues to increase (Atrostic et al. 2001; Williams and Brick 2018; De Leeuw et al. 2018; Beullens et al. 2018), more methodologists are focusing attention on which populations should be defined as "hard-to-survey". Studies suggest that immigrants, persons experiencing homelessness, renters, and cultural, ethnic, and linguistic minorities, are often classified as such (Rossi et al. 1987; Groves and Couper 1998; Stoop 2005; Massey 2014; Glasser et al. 2014; Harkness et al. 2014; Schwede et al. 2014). Other research (Berry and Gunn 2014; Dewaele et al. 2014) includes vulnerable and stigmatized populations in the hard-to-survey spectrum, which includes sexual minorities. Reports issued by the U.S. Census Bureau also point to sexual minorities among their list of hard-tocount groups requiring extra resources to ensure accurate counts (Moohn 2012; U.S. Census Bureau 2016). However, besides Lee et al. (2018), there is little published on the topic of sexual minorities as a hard-to-survey population - our article adds to this body of research.

When publicly identified as such, stigmatized and vulnerable populations can be subject to social discrimination, physical harm, and other negative outcomes (Berg and Lien 2006;

\footnotetext{
${ }^{1}$ U.S. Census Bureau, 4600 Silver Hill Rd. Washington, D.C., 20233, U.S.A. Emails: nancy.a.bates@census.gov, yazmin.argen.garcia.trejo@census.gov, and monica.j.vines@census.gov

Acknowledgments: We thank Mary Mulry, Jennifer Shopkorn, the JOS Associate Editor, and two anonymous reviewers for their comments and thoughtful feedback on a previous version. Any views expressed are those of the authors and not necessarily those of the U.S. Census Bureau. Data for the analysis come from the Census Barriers, Attitudes, Motivators Survey (CBAMS) public use microdata CBDRB-FY18-422 (August 13, 2018).
} 
2008). In the United States and worldwide, sexual minorities report widespread discrimination and greater risk of health disorders (Institute of Medicine 2011; OECD 2019). Additionally, hate crimes against gays, lesbians, bi-sexual, and transgender persons are on the rise in the United States (FBI 2017; Human Rights Campaign 2018; Zauzmer and McCoy 2019). Finally, in the United States, there is no federal law preventing employment discrimination on the basis of sexual orientation and only 26 states (and the District of Columbia) have equal employment laws that ban employment discrimination based on sexual orientation. In sum, being outwardly identified as a sexual minority carries risks regarding general well-being.

In the United States, the 2020 Census form does not include a direct measure of sexual orientation, but it will classify and make estimates of same-sex couples. Two separate questions are used to make these estimates: relationship to householder and sex of household members. Following the 2010 Census, revisions were made to the relationship question to reduce measurement error when counting same-sex couples and the result is a new relationship question with categories that clearly delineate same-sex from opposite sex couples (Bates and DeMaio 2013; DeMaio et al. 2013). As a result, for sexual minorities living with a spouse or unmarried partner, the census form clearly communicates that sexual minorities will be identified in the once-in-a-decade count. This fact, combined with the collection of names matched to addresses raises the question of whether sexual minorities may be hard-to-survey in the Census, (See Figure 1 for the 2020 Census relationship question).

More recent qualitative evidence (Ellis et al. 2017; Holzberg et al. 2017) indicates that many LGB respondents are willing to self-identify with a sexual minority group (even in government surveys) but for some, the stigma remains. According to Ellis et al. (2017,iii) “. . . a few respondents did raise issues about SOGI (Sexual Orientation and Gender Identification) questions, discussing concerns over confidentiality, or mentioning that their responses could be less protected and/or used for discrimination in the current political climate." To our knowledge, only one paper has quantitatively examined whether sexual minorities are less likely than sexual majorities to participate in surveys. Using measures of contactability and reluctance, Lee et al. (2018) found no evidence that sexual minorities

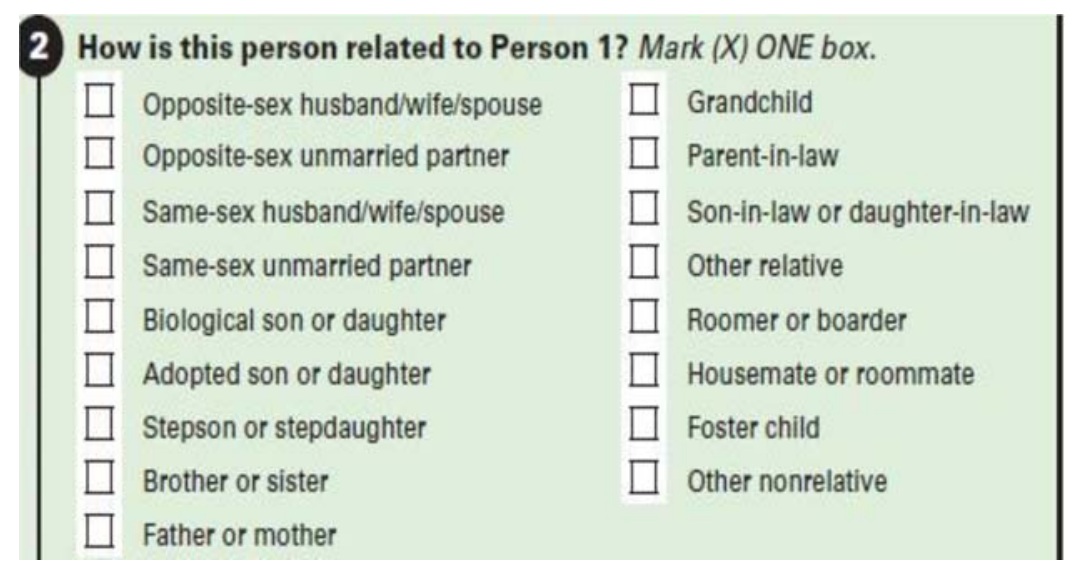

Fig. 1. 2020 U.S. Census relationship question. 
had lower participation rates in the U.S. National Health Interview Survey. Our study adds to this literature with a focus on sexual orientation and potential participation in the 2020 Census.

\section{Methods}

To better understand whether sexual minorities are, in fact, hard-to-survey we explore three proxy measures of such: level of effort, geographic location, and stated intent to participate in the 2020 Census.

With increased availability to survey paradata, it is useful to calculate level-of-effort (LOE) metrics as a proxy way to classify hard-to-survey groups (Kreuter and Olson 2013; Lee et al. 2018). The continuum of resistance theory uses such paradata to study respondents from the tail end of data collection postulating they are similar to nonrespondents in that without the extra time, resources, and effort, they would be nonrespondents (Lin and Schaeffer 1995; Meiklejohn et al. 2012). While empirical evidence is mixed on this theory, such metrics do provide clues into late responders' response patterns and behavior.

Hypothesis 1: Sexual minorities will exhibit characteristics consistent with higher levels of effort (LOE).

Next, we will examine the distribution of sexual orientation by whether the sample unit was located in a hard-to-survey census tract. This designation is based on the Census Bureau's Low Response Score (LRS) (Erdman and Bates 2017) - a summary score predicting what percentage of households in a tract will fail to self-respond in the 2020 Census - the higher the LRS score, the harder the tract is to survey.

\section{Hypothesis 2: Sexual minorities will over-represent in areas with a high LRS.}

Finally, we will use stated intent to participate in the 2020 Census as a proxy indicator for actual behavior in the Census. Specifically, we examine the hypothesis of whether sexual orientation is a significant predictor of stated intent leading to our final hypothesis:

Hypothesis 3: Sexual minorities will be less likely to indicate a positive intention to participate in the 2020 Census.

\subsection{Data: 2020 Census Barriers, Attitudes, and Motivator Study (CBAMS) Survey}

Our article analyzes the 2020 CBAMS Survey. The U.S. Census Bureau administered this survey between February 20, 2018 and April 17, 2018 to 50,000 housing units in all 50 states and the District of Columbia. The survey contained questions designed to measure the public's attitudes, knowledge, and opinions regarding the 2020 Census. The results were primarily for the purposes of developing the creative platform and messaging for the 2020 Census Communications Campaign.

The sample design for the survey included stratifying the US population into eight strata based on a census tract's racial and ethnic makeup, as well as characteristics related to Internet response. Each household in the sample received a prepaid incentive and up to five mailings inviting them to participate by mail or Internet in either English or Spanish. We used characteristics related to Internet response to determine whether a 
sampled address received an "Internet Choice" mailing strategy, where an invite to respond online was accompanied by a paper questionnaire in the first mailing or an "Internet First" that provided a paper questionnaire in the fourth mailing. (For more information on this methodology, see McGeeney et al. 2019.) There were 17,283 adults who responded to the survey, which was weighted to represent all householder adults in the United States. The final, weighted response rate was $39.4 \%$ and was calculated using a modified version of the American Association for Public Opinion Research (AAPOR) RR3 (AAPOR 2016). (See McGeeney et al. 2019 for more information on this survey.)

With the exception of reporting the overall response rate and item nonresponse rate to sexual orientation, all of our analysis and findings in this article use the public use microdata sample (PUMS) data set version of the 2020 CBAMS survey data set. The original data set was made differentially private to avoid disclosure of any personally identifiable information from 2020 CBAMS respondents (Dwork et al. 2006; Dajani et al. 2017). Each variable in the original data set was perturbed using either the multinomial generalization of randomized response mechanism for categorical variables (see McGeeney et al. 2019) or the Laplace mechanism for continuous variables with an epsilon parameter of seven. Findings in this paper include additional error from this disclosure avoidance process. To adjust for the complex sample design, we used SAS PROC SURVEYFREQ, SURVEYREG, and SURVEYMEANS for our analysis. All point and variance estimates take into account the sample design and final weights. Variance estimates were calculated using the Taylor series approximation. Any group differences noted in the text have undergone statistical testing in accordance with U.S. Census Bureau standards (U.S. Census Bureau 2013). A p-value of .05 or less was the threshold for our analysis.

\section{Results}

\subsection{Operationalizing Sexual Orientation}

The 2020 CBAMS survey asked sexual orientation as the last question in the survey (see Figure 2). The distribution for sexual orientation from the original data before editing, imputation, and noise infusion indicated that item nonresponse in the form of refusals and Don't Knows was low (1.95\% and $2.01 \%$, respectively). Table 1 shows the distribution from the CBAMS PUMS (after editing, imputation, and noise infusion). For purposes of analyses, we collapse gay or lesbian with the bisexual category to form a single category of sexual minorities. Combined, this group was 3.7\% - a number somewhat higher than the percent of sexual minorities found in the 2015 National Health Interview Survey (NHIS), one of the few nationally representative surveys to ask sexual orientation (reported as $2.4 \%$, NHIS 2015).

We also chose to exclude the Don't Know and Something Else cases for analyses. The latter decision was based on an examination of the raw write-ins to the Something Else category which revealed that, of the over 200 non-blank write-ins, only $16 \%$ represented other sexual minority labels such as "queer," "pansexual," or "asexual." Instead, the majority were write-ins such as "Christian male," "normal," and "not your business." For purposes of analyses, we used a dichotomous sexual orientation indicator of Lesbian/ Gay/Bisexual versus Straight. 


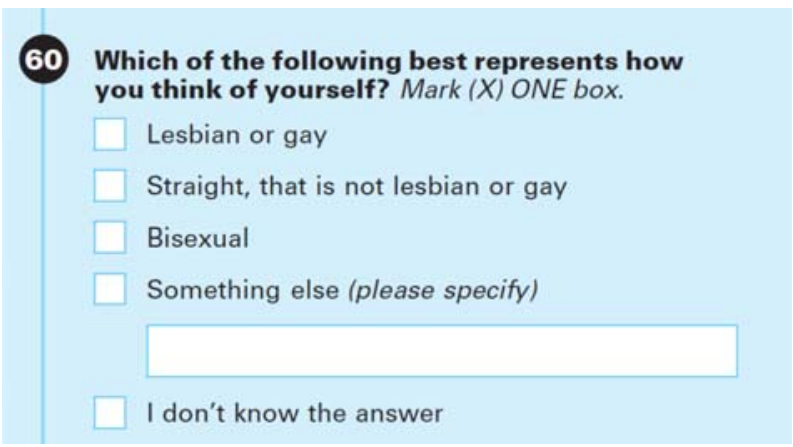

Fig. 2. 2020 CBAMS wording for the sexual orientation question.

Source: https://www2.census.gov/programs-surveys/decennial/2020/program-management/2020_cbams_ questionnaire_final.pdf?\#

To begin, we explored how sexual minorities compared to sexual majorities in terms of demographic characteristics. Overall, those who identified as a sexual minority skewed male, younger, with higher levels of education, lower income, and less likely to be married compared to those who reported being straight (see Section 6 Appendix, Table 7). Racially and ethnically, however, sexual minorities looked very similar to the rest of CBAMS respondents. In a later section when modeling intention to respond to the 2020 Census, we include many of these demographic variables as controls.

\subsection{Level of Effort}

Table 2 indicates that sexual minorities overwhelmingly responded by Internet compared to mail and at a higher rate than straight respondents $(70.2 \%$ versus $61.9 \%)$. Online preference may be due, in part, to the fact that over one-third of sexual minorities were aged $18-34.85 \%$ of sexual minority respondents also reported using the Internet "almost constantly/several times per day" compared to $68 \%$ of straight respondents (data not shown). Because online responses come in faster and at significantly lower cost than mail,

Table 1. Sexual orientation distribution.

\begin{tabular}{|l|c|}
\hline $\begin{array}{l}\text { Which of the following best represents } \\
\text { how you think of yourself? }\end{array}$ & $\begin{array}{c}\text { Weighted \% } \\
\text { (std. errors in parentheses) }\end{array}$ \\
\hline Lesbian or gay & 2.1 \\
Straight & $(0.134)$ \\
Bisexual & 92.1 \\
Something else & $(0.252)$ \\
& 1.6 \\
Don't know & $(0.119)$ \\
& 1.5 \\
N (Unweighted) & $(0.117)$ \\
\end{tabular}

Source: CBAMS 2018 PUMS file. 
Table 2. Percent responding by mail versus Internet by sexual orientation (standard errors in parentheses).

\begin{tabular}{|l|c|c|c|}
\hline & Gay/lesbian/bi & Straight & Total \\
\hline Mail & 29.8 & 38.2 & 37.8 \\
Internet & $(2.199)$ & $(0.416)$ & $(0.407)$ \\
& $(2.199)$ & 61.9 & 62.2 \\
& 579 & $10.416)$ & $(0.407)$ \\
\hline $\mathrm{N}$ (Unweighted) & & & 16016 \\
\hline$X^{2}=18.4, d f=1, p<.001$ & & & \\
\hline
\end{tabular}

Source: 2018 CBAMS PUMS.

the higher propensity for LGB to choose Internet mode of response is encouraging. Table 3 indicates that, compared to straight respondents, gay/lesbian/bisexual respondents took no more time to respond in either mode - the mean number of days for both Internet and mail did not differ significantly by sexual orientation. Taken together, these results do not indicate a higher LOE for sexual minorities.

\subsection{Low Response Score Areas}

Next, Table 4 contains the distribution of sexual orientation by whether the sample unit was designated as a "hard-to-survey" census tract. This designation is based on the U.S. Census Bureau's Low Response Score (LRS) (Erdman and Bates 2017) - a summary score predicting what percentage of households in a tract will fail to self-respond in the 2020 Census. The CBAMS used the LRS to stratify the sample by "hard-to-survey" tracts, defined as tracts with an LRS score of 30 or higher. Overall, around $7 \%$ of CBAMS respondents were located in such tracts compared to $12.4 \%$ who reported being sexual minorities $\left(X^{2}=34.1, d f=1, p<.0001\right)$. Because the CBAMS PUMS file has removed the tract identifier, it is not possible to more closely examine these areas to determine if they are concentrated in a particular geography. However, a 2017 report by The Williams Institute (UCLA School of Law) found that LGBT households disproportionately face greater economic challenges and have fewer economic resources than their straight counterparts (Conron et al. 2018). This finding is the first CBAMS evidence to support the notion that sexual minorities tend to have a higher than average prevalence in census tracts classified as "hard-to-survey."

Table 3. Mean number days until response received by mode by sexual orientation.

\begin{tabular}{|l|c|c|c|c|}
\hline & \multicolumn{2}{|c|}{ Mail } & \multicolumn{2}{c|}{ Internet } \\
\hline & Gay/lesbian/bi & Straight & Gay/lesbian/bi & Straight \\
\hline $\begin{array}{l}\text { Mean days } \\
\text { Response time }\end{array}$ & 30.8 & 32.6 & 16.0 & 16.3 \\
\hline & \multicolumn{2}{|c|}{ t-value $=-1.74, \mathrm{p}=.08$} & \multicolumn{2}{c|}{ t-value $=-.46, \mathrm{p}=.65$} \\
\hline
\end{tabular}

Source: 2018 CBAMS PUMS. 
Table 4. Percent of respondents located in hard-to-survey census tracts by sexual orientation (standard errors in parentheses).

\begin{tabular}{|l|c|c|c|}
\hline Located in hard-to-survey tract?* & Gay/lesbian/bi & Straight & Total \\
\hline Yes & $\begin{array}{c}12.4 \\
(1.605)\end{array}$ & $\begin{array}{c}6.5 \\
(0.212)\end{array}$ & $\begin{array}{c}6.7 \\
(0.212)\end{array}$ \\
No & $\begin{array}{c}87.6 \\
(1.605)\end{array}$ & $\begin{array}{c}93.3 \\
(0.212)\end{array}$ \\
\hline N (unweighted) & 579 & 16016 & 16595 \\
\hline$X^{2}=34.1, d f=1, p<.0001$ & & & \\
\hline
\end{tabular}

Source: 2018 CBAMS PUMS.

*Hard-to-survey tracts defined as having a Low Response Score $=>30$ (see Erdman and Bates 2018).

\subsection{Intent to Participate in the 2020 Census}

Finally, we examine sexual orientation and stated intent to respond in the 2020 Census. Table 5 displays the simple crosstab of sexual orientation by the CBAMS question: If the census were held today, how likely would you be to fill out the census form?

Table 5 indicates that close to three-quarters of LGB respondents said they are "extremely" or "very" likely to complete the census form in 2020 (72.2\%). Given the implicit assumption that survey response rates are lower among sexual minorities, this was an unexpected finding that we address in the Discussion section.

\subsection{Modeling Intent to Respond to Census: Sexual Orientation as a Predictor}

Table 6 contains results from two multiple regression models predicting the ordinal fivepoint scale indicating intent to respond to the 2020 Census. The first column reflects a

Table 5. Distribution of intent to participate in 2020 Census by sexual orientation (standard errors in parentheses).

\begin{tabular}{|l|c|c|c|}
\hline & $\begin{array}{c}\text { Gay/lesbian/bi } \\
\%\end{array}$ & $\begin{array}{c}\text { Straight } \\
\%\end{array}$ & $\begin{array}{c}\text { Total } \\
\%\end{array}$ \\
\hline 5- Extremely likely & 44.2 & 29.5 & 30.1 \\
4- Very likely & $(2.417)$ & $(0.406)$ & $(0.403)$ \\
& 28.0 & 38.2 & 37.8 \\
3- Somewhat likely & $(2.170)$ & $(0.444)$ & $(0.435)$ \\
2- Not too likely & 23.2 & 25.0 & 24.9 \\
& $(2.115)$ & $(0.412)$ & $(0.404)$ \\
1- Not at all likely & 3.4 & $(0.226)$ & 5.0 \\
& $(1.033)$ & 2.3 & $(0.221)$ \\
& $(0.676)$ & $(0.147)$ & 2.2 \\
\hline $\mathrm{N}$ (unweighted) & $(0.150)$ & 16016 & 16595 \\
\hline$X^{2}=68.6, d f=4, p<.0001$ & 579 & & \\
\hline
\end{tabular}

Source: 2018 CBAMS PUMS. 
Table 6. Regression predicting INTENT (likelihood to participate in the Census along five-point Likert scale).

\begin{tabular}{|c|c|c|c|c|}
\hline & \multicolumn{2}{|c|}{ Model 1} & \multicolumn{2}{|c|}{ Model 2} \\
\hline & Unstd. coeff. & Std. coeff. & Unstd. coeff. & Std. coeff \\
\hline Intercept & $\begin{array}{l}2.739 * * * \\
(0.054)\end{array}$ & 0.000 & $\begin{array}{l}2.423 * * * \\
(0.052)\end{array}$ & 0.000 \\
\hline $\begin{array}{l}\text { Predictor: sexual } \\
\text { orient. (straight) } \\
\text { Gay/lesbian/bisexual } \\
\text { Control variables: }\end{array}$ & $\begin{array}{l}0.314 * * * \\
(0.048)\end{array}$ & 0.062 & $\begin{array}{l}0.231 * * * \\
(0.046)\end{array}$ & 0.046 \\
\hline Age & $\begin{array}{l}0.110 * * * \\
(0.007)\end{array}$ & 0.172 & $\begin{array}{l}0.077 * * * \\
(0.007)\end{array}$ & 0.120 \\
\hline Female & $\begin{array}{c}0.006 \\
(0.018)\end{array}$ & 0.003 & $\begin{array}{l}0.062^{* *} \\
(0.017)\end{array}$ & 0.032 \\
\hline $\begin{array}{l}\text { Race/Origin } \\
\text { (NH, WHITE) }\end{array}$ & & & & \\
\hline Hispanic & $\begin{array}{l}0.147 * * * \\
(0.032)\end{array}$ & 0.050 & $\begin{array}{l}0.138 * * * \\
(0.030)\end{array}$ & 0.047 \\
\hline $\mathrm{NH}$, black & $\begin{array}{r}-0.001 \\
(0.030)\end{array}$ & 0.000 & $\begin{array}{l}0.083 * * \\
(0.028)\end{array}$ & 0.028 \\
\hline $\mathrm{NH}$, asian & $\begin{array}{l}-0.280 * * * \\
(0.045)\end{array}$ & -0.054 & $\begin{array}{c}-0.126 * * \\
(0.043)\end{array}$ & -0.025 \\
\hline $\mathrm{NH}$, other race & $\begin{array}{r}-0.052 \\
(0.049)\end{array}$ & -0.010 & $\begin{array}{r}-0.002 \\
(0.045)\end{array}$ & 0.000 \\
\hline Education & $\begin{array}{l}0.127 * * * \\
(0.006)\end{array}$ & 0.220 & $\begin{array}{l}0.048 * * * \\
(0.006)\end{array}$ & 0.084 \\
\hline Income & $\begin{array}{l}0.040^{* * * *} \\
(0.005)\end{array}$ & 0.088 & $\begin{array}{c}0.006 \\
(0.005)\end{array}$ & 0.013 \\
\hline Rent (Homeowner) & $\begin{array}{r}-0.008 \\
(0.022)\end{array}$ & -0.004 & $\begin{array}{c}0.014 \\
(0.020)\end{array}$ & 0.007 \\
\hline Foreign Born & $\begin{array}{r}-0.062 \\
(0.032)\end{array}$ & -0.022 & $\begin{array}{c}0.007 \\
(0.030)\end{array}$ & 0.003 \\
\hline Non-English Spoken & $\begin{array}{r}-0.074 * \\
(0.033)\end{array}$ & -0.030 & $\begin{array}{c}-0.055 \\
(0.030)\end{array}$ & -0.022 \\
\hline Marital status (married) & & & & \\
\hline $\begin{array}{l}\text { Div/separated/ } \\
\text { widowed }\end{array}$ & $\begin{array}{r}-0.054^{*} \\
(0.022)\end{array}$ & -0.025 & $\begin{array}{r}-0.036 \\
(0.020)\end{array}$ & -0.017 \\
\hline Never married & $\begin{array}{c}-0.057^{*} \\
(0.028)\end{array}$ & -0.024 & $\begin{array}{r}-0.046 \\
(0.026)\end{array}$ & -0.019 \\
\hline Census knowledge & & & $\begin{array}{l}0.113 * * * \\
(0.003)\end{array}$ & 0.331 \\
\hline $\begin{array}{l}\text { Confidentiality } \\
\text { concerns }\end{array}$ & & & $\begin{array}{c}-0.024 * * \\
(0.008)\end{array}$ & -0.027 \\
\hline Civic participation & & & $\begin{array}{l}0.052 * * * \\
(0.003)\end{array}$ & 0.149 \\
\hline
\end{tabular}

Note: $* * * \mathrm{p}$-value $<0.001, * * \mathrm{p}<0.01, * \mathrm{p}<0.05$. Standard errors in parenthesis. NH: stands for NonHispanic. Logistic regressions were also performed with $1=$ Extremely likely/Very Likely and $0=$ Somewhat likely/Not too likely/Not at all likely. Results were very similar with no changes in the direction or significance of Sexual Orientation in either model.

Source: Authors' calculations from CBAMS PUMS 2020. 
model containing the dichotomous sexual orientation as a predictor, along with a battery of demographic control variables. Demographic controls were selected based on one of two criteria; first, whether previous studies (as noted in the introduction) have identified the characteristic as being associated with survey nonresponse (e.g., race and ethnic minority, foreign born, and language minority) and/or second, whether the characteristic was found to skew for sexual minorities from the general population (i.e., age, sex, education, income and home ownership, as displayed in Section 6 Appendix Table 7).

In the first model, sexual orientation is a significant predictor with gay/lesbian/bisexual respondents indicating a higher likelihood of responding to the 2020 Census compared to straight respondents. While this finding comes with the caveats noted in the limitation section that follows, it is the only empirical evidence we are aware of to measure the relationship between sexual orientation and propensity to cooperate in a survey or census. The demographic only model had an R-square of 0.10 .

The second column of Table 6 adds several important constructs found to predict census response behavior in the 2010 Census. In a survey that matched actual census behavior to Census knowledge, attitudes, and exposure to the Census advertising, Datta et al. (2012) reported that the higher the knowledge of Census uses and trust in Census data confidentiality, the higher the likelihood of having completed and mailed back the Census form. Additionally, Bates and Mulry (2012) reported that respondents having a civically-inclined "mindset" were also more likely to mail back a census form. Accordingly, in the second model we include three categorical indices based on three batteries of CBAMS questions. The first indicates the number of correct answers that respondents provided regarding applications/uses of Census data, a second reflects the level of civic participation, and a third measures the degree of concern about the confidentiality of the Census (see Section 6 Appendix for items comprising the indices).

In the second model, sexual orientation (gay/lesbian/bisexual) remains a positive and significant predictor of intent to respond. In addition, age, sex (female) and education also had significant and positive coefficients. Somewhat surprisingly, both Hispanics and blacks expressed a higher likelihood to participate compared to non-Hispanic whites, while Asians had a lower stated intent compared to non-Hispanic whites. Neither nativity, non-English language spoken at home, owner/renter status, nor marital status were significant predictors (at the .05 level).

Additionally, all three indices are significant and in line with prior studies. Specifically, higher knowledge and higher civic engagement is associated with higher intent to respond. Alternatively, the higher the privacy concerns, the lower the stated intent to respond. Addition of the knowledge, attitude, and confidentiality measures more than doubles the Rsquare from .10 to .23 . We examined whether sexual minorities varied significantly from straights on all three indices (see Section 6 Appendix, Tables 8, 9, and 10). No significant differences were found for knowledge or confidentiality concerns. However, LGB respondents reported a significantly higher number of activities such as voting, participating in a protest or rally, or volunteering for an organization (see Section Appendix, Table 9).

\section{Limitations}

Our analyses come with a number of important limitations. First, our data come from a nationally representative sample of US households drawn from the U.S. Census Bureau's 
Master Address File (MAF). While the sample frame contains some information (e.g., whether the unit is a single or multiunit, urban or rural) we have no frame information about the residents' sexual orientation. Furthermore, sexual orientation is not a demographic collected in the American Community Survey or Decennial Census. Consequently, we have no "gold standard" benchmarks to assess potential level of nonresponse bias. Second, our inferences are based on sexual minorities willing to identify as such in a government-sponsored survey. These respondents may or may not be similar to sexual minorities as a whole. Additionally, due to the small population size of sexual minorities, we cannot analyze lesbians, gay men, and bisexuals separately. Finally, previous research indicates that stated intent to participate in a census does not perfectly align with actual behavior. Research suggests that even individuals who report a commitment to participate may not follow through on their intention. Ajzen (1991) argues that there is often a gap between a person's intended and actual behavior, and unforeseen costs and circumstances ultimately prevent some people from carrying out their intended behavior. For example, in a 2010 Census match study, households who reported in a pre-census survey they would "definitely" mail back a census form were found, in fact, to have actually self-responded only $70.8 \%$ of the time (Datta et al. 2012).

\section{Discussion}

Marginalized and stigmatized groups are routinely classified as hard-to-survey populations and sexual minorities are commonly included in this category. Despite this implicit assumption, there is little empirical evidence on the topic. Our article adds to the literature on this assumption by examining whether sexual minorities (1) exhibit characteristics consistent with a population requiring higher levels of effort to secure participation, (2) tend to be located in hard-to-count areas, and/or (3) have lower intention to participate in the 2020 Census.

For the most part, our data did not support our hypotheses. The data did not support the notion that gay, lesbian, and bisexual respondents required higher levels of effort compared to sexual majorities; however, they were found to over-represent in census tracts classified as hard-to-survey as measured by the U.S. Census Bureau's Low Response Score.

We found that over $44.2 \%$ of sexual minorities said they were "extremely likely" to participate in the 2020 Census compared to less than $30 \%$ of straight respondents. Additionally, we found that sexual orientation (LGB) was a significant (positive) predictor of intent to participate, even after controlling for demographics such as age, nativity, race/ethnicity, education, level of civic participation, census knowledge, and privacy/confidentiality concerns.

To explain this somewhat surprising finding, we turn to the Groves and Couper (1998) conceptual model of survey cooperation. In this model, the social environment plays a critical role in the outcome of a survey request. Surveys are subject to societal change, for example, public opinion among the members of a society, level of trust in government, political alienation, and privacy and confidentiality concerns are all ways to measure the social climate of an environment. In addition, although the social environment is considered to be a fairly fixed attribute that the researcher is powerless to control, Groves and Couper (1998) warn that it should not be ignored. This is because it influences decision-making, its importance changes over time, and it exhibits variation among 
subgroups of the population. We believe the social climate is particularly relevant for sexual minorities for a variety of reasons and that may help explain our findings.

First, public opinion in the United States indicates a dramatic change in opinion towards the LGB community. Support towards same-sex marriage has drastically increased in the last decade (See Hatzenbuehler et al. 2017; Masci et al. 2017). Moreover, there is also growing majority support for civil rights for the LGB community. By 2014, " $89 \%$ of Americans say a gay person should be allowed to give a speech in their community. . . 83\% allowed to teach and $81 \%$ support keeping a book written by a gay person" (NORC 2014).

Recent research shows that nonresponse rates to sexual orientation questions have declined over time among older adults (Fredriksen-Goldsend and Kim 2014; Fredriksen-Goldsen et al. 2015). There are still age cohort differences, as it is true that compared to younger cohorts, $65+$ adults are still more likely to select "don't know/not sure" or refusals. However, even “don't know/not sure" and refusal rates have decreased over time (Saewyc 2011). These trends may be tied to sexual minorities feeling less ostracized in US society, with less stigma when self-identifying as gay, lesbian, or bisexual in survey data collections.

On the other hand, in the United States in the last few years, law officials and watchdog organizations have also reported a sharp increase in hate crimes toward the LGB community. Additionally, the current US administration has enacted policies that negatively impact sexual and gender minorities, including the proposed ban of transgender persons to serve in the military, new state level bans on same-sex couple adoptions, and the policy to end same-sex partner visas of diplomats (Durkin 2018). The outcome of recent and pending court decisions could also have negative outcomes for sexual and gender minorities (Law 2019; Allen 2018; Masterpiece Cakeshop versus Colorado Civil Rights Commission 2018). The result of such social climate events have spurred renewed protests and local activism by the LGB community. This may explain why a large portion of sexual minorities exhibited higher participation in activities such as voting, signing petitions, volunteering in organizations, and participating in a protest or rally.

The inclusion of a sexual orientation question and a sufficiently large sample size in the CBAMS enabled the U.S. Census Bureau to obtain research-based insights to specifically inform tailoring and targeting to sexual minorities for the first time. In terms of messaging, sexual minorities were more likely than straight respondents to select the following two reasons as most motivating: 'It determines how many elected representatives my state has in Congress' and 'It is used to enforce civil rights laws'. As such, messages in introductions, prenotices, survey invitations and paid ads specifically developed for sexual minorities should emphasize these themes. Additionally, sexual minorities were more likely to prefer online forms to paper ones, making mode targeting an important consideration - particularly in the 2020 Census, as the form can be submitted online. Finally, advertisements will be aimed at media specifically consumed by the LGB population with imagery that resonates (e.g., featuring same sex couples); partners and trusted voices closely connected to this community will also relay the importance of participation in the 2020 Census.

Given the scarcity of information about sexual minorities and surveys, we view our results as another step toward answering the question of whether sexual minorities are a hard-to-survey population. Given the polarized components of the social climate that affect sexual minorities, we cannot say definitively whether the stigma and prejudice has 
decreased enough to rethink the assumption of LGBs as a hard-to-survey population. However, we did uncover clues that may help ensure their participation in future censuses and surveys.

\section{Appendix}

Table 7. Demographic distributions (\%) by sexual orientation: CBAMS PUMS 2018 (standard errors in parentheses).

\begin{tabular}{|c|c|c|c|}
\hline & $\begin{array}{c}\text { Gay/lesbian/bi } \\
\%\end{array}$ & $\begin{array}{c}\text { Straight } \\
\%\end{array}$ & $\begin{array}{c}\text { Total } \\
\%\end{array}$ \\
\hline $\begin{array}{l}\text { Male } \\
\text { Female }\end{array}$ & $\begin{array}{c}58.68 \\
(2.412) \\
41.32 \\
(2.412)\end{array}$ & $\begin{array}{c}49.09 \\
(0.460) \\
50.91 \\
(0.460)\end{array}$ & $\begin{array}{c}49.46 \\
(0.452) \\
50.54 \\
(0.452)\end{array}$ \\
\hline Total & 579 & 16016 & 16595 \\
\hline \multicolumn{4}{|l|}{$X^{2}=22.7, d f=1, p=<.0001$} \\
\hline $\begin{array}{l}18-24 \\
25-34 \\
35-44 \\
45-54 \\
55-64 \\
65+\end{array}$ & $\begin{array}{c}10.80 \\
(1.759) \\
26.09 \\
(2.260) \\
19.60 \\
(2.020) \\
16.43 \\
(1.675) \\
16.66 \\
(1.677) \\
10.42 \\
(1.197)\end{array}$ & $\begin{array}{c}3.57 \\
(0.211) \\
13.88 \\
(0.361) \\
16.89 \\
(0.380) \\
16.47 \\
(0.326) \\
23.01 \\
(0.377) \\
26.19 \\
(0.363)\end{array}$ & $\begin{array}{c}3.85 \\
(0.214) \\
14.35 \\
(0.358) \\
16.99 \\
(0.373) \\
16.47 \\
(0.320) \\
22.76 \\
(0.368) \\
25.58 \\
(0.353)\end{array}$ \\
\hline Total (unweighted) & 579 & 16016 & 16595 \\
\hline \multicolumn{4}{|l|}{$X^{2}=221.06, d f=5, p=<.0001$} \\
\hline $\begin{array}{l}\text { Hispanic } \\
\text { Non-Hispanic-White } \\
\text { Non-Hispanic-Black } \\
\text { Non-Hispanic-Asian } \\
\text { Non-Hispanic-Other }\end{array}$ & $\begin{array}{c}12.58 \\
(1.538) \\
66.00 \\
(2.339) \\
13.18 \\
(1.841) \\
3.43 \\
(0.749) \\
4.82 \\
(1.067)\end{array}$ & $\begin{array}{c}12.43 \\
(0.285) \\
68.77 \\
(0.385) \\
11.99 \\
(0.278) \\
3.66 \\
(0.142) \\
3.15 \\
(0.149)\end{array}$ & $\begin{array}{c}12.44 \\
(0.280) \\
68.66 \\
(0.378) \\
12.03 \\
(0.274) \\
3.66 \\
(0.139) \\
3.21 \\
(0.149)\end{array}$ \\
\hline Total (unweighted) & 579 & 16016 & 16595 \\
\hline \multicolumn{4}{|l|}{$X^{2}=6.8, d f=4, p=0.3272$} \\
\hline $\begin{array}{l}\text { Married } \\
\text { Not married }\end{array}$ & $\begin{array}{c}23.48 \\
(1.918) \\
76.52 \\
(1.918)\end{array}$ & $\begin{array}{c}53.60 \\
(0.457) \\
46.40 \\
(0.457)\end{array}$ & $\begin{array}{c}52.44 \\
(0.449) \\
47.56 \\
(0.449)\end{array}$ \\
\hline
\end{tabular}


Table 7. Continued.

\begin{tabular}{|c|c|c|c|}
\hline & $\begin{array}{c}\text { Gay/lesbian/bi } \\
\%\end{array}$ & $\underset{\%}{\text { Straight }}$ & $\begin{array}{c}\text { Total } \\
\%\end{array}$ \\
\hline Total (unweighted) & 579 & 16016 & 16595 \\
\hline \multicolumn{4}{|l|}{$X^{2}=223.9, d f=1, p=<.0001$} \\
\hline $\begin{array}{l}\text { Less than high school } \\
\text { High school graduates, no college } \\
\text { Some college or associate degree } \\
\text { Bachelor's degree or higher } \\
\text { Total (unweighted) }\end{array}$ & $\begin{array}{l}8.21 \\
(1.701) \\
15.77 \\
(2.030) \\
32.71 \\
(2.329) \\
43.32 \\
(2.336) \\
579\end{array}$ & $\begin{array}{c}9.89 \\
(0.308) \\
24.64 \\
(0.418) \\
31.21 \\
(0.429) \\
34.26 \\
(0.402) \\
16016\end{array}$ & $\begin{array}{l}9.82 \\
(0.303) \\
24.30 \\
(0.410) \\
31.27 \\
(0.422) \\
34.61 \\
(0.396) \\
16595\end{array}$ \\
\hline \multicolumn{4}{|l|}{$X^{2}=36.8, d f=3, p=<.001$} \\
\hline $\begin{array}{l}\text { Own } \\
\text { Rent/Occupied without payment } \\
\text { of rent }\end{array}$ & $\begin{array}{c}41.26 \\
(2.319) \\
58.74 \\
(2.319)\end{array}$ & $\begin{array}{c}65.29 \\
(0.459) \\
34.71 \\
(0.459)\end{array}$ & $\begin{array}{r}64.36 \\
(0.452) \\
35.64 \\
(0.452)\end{array}$ \\
\hline Total (unweighted) & 579 & 16016 & 16595 \\
\hline \multicolumn{4}{|l|}{$X^{2}=155.0, d f=1, p=<.0001$} \\
\hline $\begin{array}{l}\text { Less than USD34,999 } \\
\text { USD35,000 - USD74,999 } \\
\text { USD75,000 - USD149,999 } \\
\text { USD150,000 and above }\end{array}$ & $\begin{array}{l}42.71 \\
(2.488) \\
28.72 \\
(2.160) \\
19.03 \\
(1.787) \\
9.54 \\
(1.158)\end{array}$ & $\begin{array}{c}33.30 \\
(0.429) \\
30.43 \\
(0.427) \\
24.47 \\
(0.381) \\
11.80 \\
(0.269)\end{array}$ & $\begin{array}{l}33.66 \\
(0.424) \\
30.37 \\
(0.419) \\
24.26 \\
(0.373) \\
11.71 \\
(0.262)\end{array}$ \\
\hline Total (unweighted) & 579 & 16016 & 16595 \\
\hline \multicolumn{4}{|l|}{$X^{2}=27.0, d f=3, p=<.0001$} \\
\hline $\begin{array}{l}\text { U.S. born } \\
\text { Foreign born }\end{array}$ & $\begin{array}{l}89.31 \\
(1.463) \\
10.69 \\
(1.463)\end{array}$ & $\begin{array}{c}86.14 \\
(0.301) \\
13.86 \\
(0.301)\end{array}$ & $\begin{array}{c}86.26 \\
(0.294) \\
13.74 \\
(0.294)\end{array}$ \\
\hline Total (unweighted) & 579 & 16016 & 16595 \\
\hline$X^{2}=27.0, d f=3, p=<.0001$ & & & \\
\hline
\end{tabular}

Source: 2018 CBAMS PUMS. 
Table 8. Distribution of census knowledge index in 2020 census by sexual orientation (standard errors in parentheses).

\begin{tabular}{|c|c|c|c|}
\hline & Gay/lesbian/bi & Straight & Total \\
\hline $\begin{array}{l}\text { High knowledge }(8-11) \\
\text { Medium knowledge }(4-7) \\
\text { Low knowledge }(0-3)\end{array}$ & $\begin{array}{c}31.19 \\
(2.153) \\
44.10 \\
(2.425) \\
24.71 \\
(2.293)\end{array}$ & $\begin{array}{c}29.76 \\
(0.405) \\
47.71 \\
(0.460) \\
22.54 \\
(0.397)\end{array}$ & $\begin{array}{c}29.81 \\
(0.398) \\
47.57 \\
(0.452) \\
22.62 \\
(0.392)\end{array}$ \\
\hline $\mathrm{N}$ (unweighted) & 579 & 16016 & 16595 \\
\hline$X^{2}=3.4, d f=2, p<.1842$ & & & \\
\hline
\end{tabular}

Source: 2018 CBAMS PUMS.

Table 9. Distribution of civic participation index in 2020 census by sexual orientation (standard errors in parentheses).

\begin{tabular}{|c|c|c|c|}
\hline & Gay/lesbian/bi & Straight & Total \\
\hline $\begin{array}{l}\text { High civic engagement }(7-10) \\
\text { Medium civic engagement }(4-6) \\
\text { Low civic engagement }(0-3)\end{array}$ & $\begin{array}{c}44.19 \\
(2.413) \\
31.56 \\
(2.282) \\
24.25 \\
(2.179)\end{array}$ & $\begin{array}{c}26.09 \\
(0.388) \\
34.66 \\
(0.434) \\
39.25 \\
(0.450)\end{array}$ & $\begin{array}{c}26.79 \\
(0.386) \\
34.54 \\
(0.427) \\
38.669 \\
(0.441)\end{array}$ \\
\hline $\mathrm{N}$ (unweighted) & 579 & 16016 & 16595 \\
\hline$X^{2}=112.7, d f=2, p<.0001$ & & & \\
\hline
\end{tabular}

Source: 2018 CBAMS PUMS.

Table 10. Distribution of confidentiality index in 2020 census by sexual orientation (standard errors in parentheses).

\begin{tabular}{|l|c|c|c|}
\hline & Gay/lesbian/bi & Straight & Total \\
\hline No confidentiality concern & $\begin{array}{c}63.78 \\
(2.360)\end{array}$ & $\begin{array}{c}63.11 \\
(0.440)\end{array}$ & $\begin{array}{c}63.14 \\
(0.432)\end{array}$ \\
& $\begin{array}{c}36.22 \\
(2.360)\end{array}$ & $\begin{array}{c}36.86 \\
(0.440)\end{array}$ & $(0.432$ \\
\hline Confidentiality concern & 579 & 16016 & 16595 \\
\hline N (unweighted) & & & \\
\hline$X^{2}=0.1, d f=1, p<.7820$ & & & \\
\hline
\end{tabular}

Source: 2018 CBAMS PUMS. 
Question used to create Civic Engagement Index:

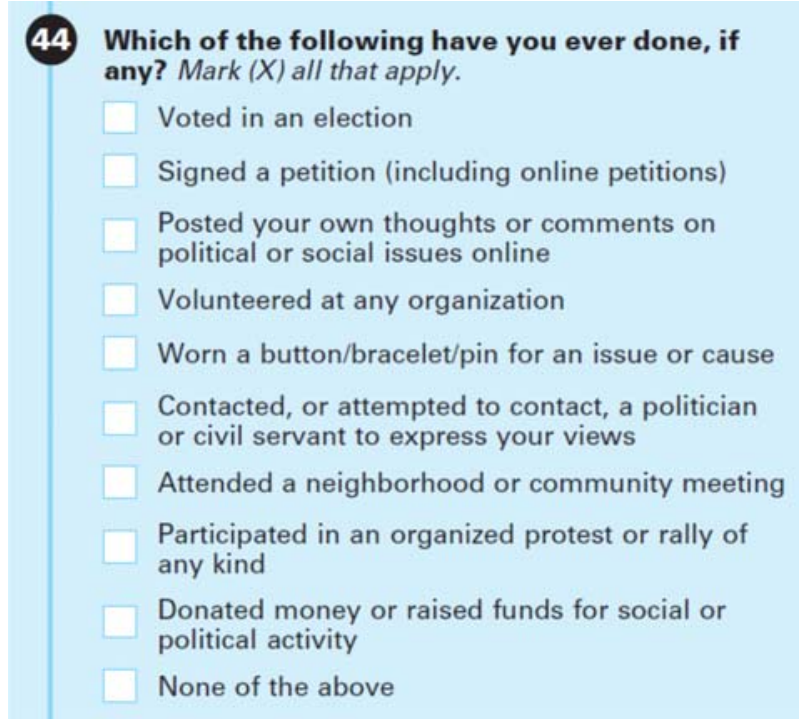

Source: 2020 CBAMS survey

Questions used to create the Concerns about Confidentiality Index:

38 How concerned are you, if at all, that the Census Bureau will not keep answers to the 2020 Census confidential? Mark (X) ONE box.
Extremely concerned
Very concerned
Somewhat concerned
Not too concerned
Not at all concerned

39 How concerned are you, if at all, that the Census Bureau will share answers to the 2020 Census with other government agencies? Mark ( $X$ ) ONE box.
Extremely concerned
Very concerned
Somewhat concerned
Not too concerned
Not at all concerned

40 How concerned are you, if at all, that the answers you provide to the 2020 Census will be used against you? Mark $(X)$ ONE box.
Extremely concerned
Very concerned
Somewhat concerned
Not too concerned
Not at all concerned

Source: 2020 CBAMS survey 
Questions used to create Knowledge Index:

The following questions are about the 2020 Census in general. There is no need to look up this information. As you understand it, will the 2020 Census be used in any of the following ways or not?

9 Is the census used to decide how much money communities will get from the government, or is it not used for this? Mark $(X)$ ONE box.
Yes, used for this
No, not used
Don't know

10 Is the census used to determine the rate of unemployment, or is it not used for this? Mark $(X)$ ONE box.

Yes, used for this

No, not used

Don't know

11 Does the census count both citizens and non-citizens, or only citizens? Mark $(X)$ ONE box.

Yes, used for counting both citizens and non-citizens

No, used only for counting citizens

Don't know

12 Is the census used to determine property taxes. or is it not used for this? Mark $(X)$ ONE box.

Yes, used for this

No, not used

Don't know

13 Is the census used to decide how many representatives each state will have in Congress. or is it not used for this? Mark (X) ONE box.

Yes, used for this

No, not used

Don't know
14 Is the census used to help the police and FBI keep track of people who break the law, or is it not used for this? Mark $(X)$ ONE box.

Yes, used for this

No, not used

Don't know

15 Is the census used to locate people living in the country without documentation, or is it not used for this? Mark $(X)$ ONE box.

Yes, used for this

No, not used

Don't know

16 Is the census used to see what changes have taken place in the size, location, and characteristics of the people in the United States, or is it not used for this? Mark $(X)$ ONE box.

$\square$ Yes, used for this

No, not used

Don't know

Does the law require you to answer the census questions, or is this not required by law? Mark (X) ONE box.

$\square$ Yes, required by law

No, not required by law

Don't know

18 Is the Census Bureau required by law to keep information confidential, or is this not required by law? Mark $(X)$ ONE box.

Yes, required by law

No, not required by law

Don't know

19 Does the U.S. Constitution require that the census be conducted, or is this not something the Constitution requires? Mark $(X)$ ONE box.

Yes, Constitution requires

No, Constitution does not require

Don't know

Source: 2020 CBAMS survey

\section{References}

AAPOR. 2016. Standard Definitions Final Dispositions of Case Codes and Outcome

Rates for Surveys. 9th edition. Available at: https://www.aapor.org/AAPOR_Main/ media/publications/Standard-Definitions20169theditionfinal.pdf (accessed October 2019). 
Ajzen, I. 1991. "The Theory of Planned Behavior.” Organizational Behavior and Human Decision Processes 50(2): 179-211. DOI: https://doi.org/10.1016/0749-5978(91) 90020-T.

Allen, S. 2018. "These Five Court Cases Could Change the Future of LGBT Rights." The Daily Beast, July 7, 2018. Available at: https:/www.thedailybeast.com/these-fivecourt-cases-could-change-the-future-of-lgbt-rights (accessed September 2019).

Atrostic, B.K., N. Bates, G. Burt, and A. Silberstein. 2001. "Nonresponse in US Government Household Surveys: Consistent Measures, Recent Trends, and New Insights.” Journal of Official Statistics 17(2): 209-226.

Bates, N. and T.J. DeMaio. 2013. "Measuring Same-Sex Relationship." Contexts 12(1): 66-69. DOI: https://doi.org/10.1177/1536504213476251.

Bates, N. and M. Mulry. 2012. "Did the 2010 Census Social Marketing Campaign Shift Public Mindsets?" In proceedings of the annual conference of the American Association for Public Opinion Research, May 17, 2012. Orlando, FL: American Association for Public Opinion Research. Available at: http://www.aapor.org/AAPOR_Main/media/ AnnualMeetingProceedings/2012/02_Bates-and-Mulry_A6-presentation.pdf (accessed September 2019).

Berg, N. and D. Lien. 2006. "Same-Sex Sexual Behaviour: US Frequency Estimates from Survey Data with Simultaneous Misreporting and Non-Response." Applied Economics 38(7): 757-769. DOI: https://doi.org/10.1080/00036840500427114.

Berg, N. and D. Lien. 2008. "Sexual Orientation and Self-Reported Lying." Review of Economics of the Household 7(1): 83-104. DOI: https://doi.org/10.1007/s11150-0089038-1.

Berry, S.H. and P.P. Gunn. 2014. "Conducting research on vulnerable and stigmatized populations.” In Hard-to-Survey Populations, edited by R. Tourangeau, B. Edwards, T.P. Johnson, K.M. Wolter, and N. Bates. Cambridge: Cambridge University Press.

Beullens, K., G. Loosveldt, C. Vandenplas, and I. Stoop. 2018. "Response rates in The European Social Survey: Increasing, decreasing, or a matter of fieldwork efforts?" Survey Methods: Insights from the Field. DOI: https://doi.org/10.13094/SMIF-201800003.

Conron, K.J., S.K. Goldberg, and C.T. Halpern. 2018. "Socioeconomic Status of Sexual Minorities." Los Angeles: The Williams Institute. UCLA School of Law. Available at: https://williamsinstitute.law.ucla.edu/research/ses-sexual-minorities/ (accessed September 2018).

Dajani, A.N., A.D. Lauger, P.E. Singer, D. Kifer, J.P. Reiter, A.M. S, L. Garfinkel, S.A. Dahl, M. Graham, V. Karwas, H. Kim, P. Leclerc, I.M. Schmutte, W.N. Sexton, L. Vilhuber, and J.M. Abowd. 2017. "The modernization of statistical disclosure limitation at the U.S. Census Bureau." Washington, D.C.: U.S. Census Bureau. Available at: https://www2.census.gov/cac/sac/meetings/2017-09/statistical-disclosure-limitation. pdf?\# (accessed September 2019).

Datta, A.R., T. Yan, D. Evans, S. Pedlow, B. Spencer, and R. Bautista. 2012. “2010 Census Integrated Communications Program Evaluation (CICPE)." 2010 Census Planning Memoranda Series. Suitland, MD: U.S. Census Bureau and NORC at the 
University of Chicago. Available at: https://census.gov/content/dam/Census/library/ publications/2012/dec/2010_cpex_167.pdf (accessed September 2019).

De Leeuw, E., J. Hox, and A. Luiten. 2018. "International Nonresponse Trends across Countries and Years: An analysis of 36 years of Labour Force Survey data." Survey Insights: Methods from the Field. DOI: https://doi.org/10.13094/SMIF-201800008.

DeMaio, T.J., N. Bates, and M. O’Connell. 2013. "Exploring Measurement Error Issues in Reporting Same-Sex Couples." Public Opinion Quarterly 77(S1): 145-158. DOI: https://doi.org/10.1093/poq/nfs066.

Dewaele, A., M. Caen, and A. Buysse. 2014. "Comparing Survey and Sampling Methods for Reaching Sexual Minority Individuals in Flanders." Journal of Official Statistics 30(2): 251-275. DOI: http://dx.doi.org/10.2478/jos-2014-0016.

Durkin, E. 2018. "US Begins Denying Visas for Same-Sex Domestic Partners of Diplomats." The Guardian, October 2, 2018. Available at: https://www.theguardian. com/world/2018/oct/02/us-visas-same-sex-domestic-partners-diplomats-un-staffdenied (accessed September 2019).

Dwork, C., F. McSherry, K. Nissim, and A. Smith. 2006. "Calibrating noise to sensitivity in private data analysis." In Theory of Cryptography. TCC 2006. Lecture Notes in Computer Science, edited by S. Halevi and T. Rabin, 265-284. Berlin, Heidelberg: Springer. DOI: http://dx.doi.org/10.1007/11681878_14.

Ellis, R., M. Virgile, J. Holzberg, D.V. Nelson, J. Edgar, P. Phipps, and R. Kaplan. 2017. "Assessing the Feasibility of Asking about Sexual Orientation and Gender Identity in the Current Population Survary: Results from Cognitive Interviews." Washington, D.C.: U.S. Bureau of Labor Statistics. Available at: https://www.bls.gov/osmr/researchpapers/2017/html/st170210.htm (accessed September 2019).

Erdman, C. and N. Bates. 2017. "The Low Response Score (LRS) A Metric to Locate, Predict, and Manage Hard-to-Survey Populations." Public Opinion Quarterly 81(1): 144-156. DOI: https://doi.org/10.1093/poq/nfw040.

FBI. 2017. "2017 Hate Crime Statistics Released. Report Shows More Departments Reporting Hate Crime Statistics.” News, November 13, 2018. Available at: https://www. fbi.gov/news/stories/2017-hate-crime-statistics-released-111318 (accessed September 2019).

Fredriksen-Goldsen, K.I. and H. Kim. 2014. "Count Me in: Response to Sexual Orientation Measures among Older Adults." Research on Aging 37(5): 464-480. DOI: https://doi.org/10.1177/0164027514542109.

Fredriksen-Goldsen, K.I., H. Kim, C. Shiu, J. Goldsen, and C.A. Emlet. 2015. "Successful Aging among LGBT Older Adults: Physical and Mental Health-Related Quality of Life by Age Group." The Gerontologist 55(1): 154-168. DOI: https://doi.org/10.1093/ geront/gnu081.

Glasser, I., E. Hirsch, and A. Chan. 2014. "Reaching and enumerating homeless populations." In Hard-to-Survey Populations, edited by R. Tourangeau, B. Edwards, T.P. Johnson, K.M. Wolter, and N. Bates, 180-200. Cambridge: Cambridge University Press.

Groves, R.M. and M.P. Couper. 1998. Nonresponse in Household Surveys. New York: Wiley. 
Harkness, J., M. Stange, K.L. Cibelli, P. Mohler, and B. Pennell. 2014. "Surveying cultural and linguistic minorities." In Hard-to-Survey Populations, edited by R. Tourangeau, B. Edwards, T.P. Johnson, K.M. Wolter, and N. Bates, 245-269. Cambridge: Cambridge University Press.

Hatzenbuehler, M.L., A.R. Flores, and G.J. Gates. 2017. "Social Attitudes Regarding Same-sex Marriage and LGBT Health Disparities: Results from a National Probability Sample." Journal of Social Issues 73(3): 508-528. DOI: https://doi.org/10.1111/ josi.12229.

Holzberg, J., R. Ellis, M. Virgile, D. Nelson, J. Edgar, P. Phipps, and R. Kaplan. 2017. "Assessing the Feasibility of Asking about Gender Identity in the Current Population Survey. Results from Focus Groups with members of the Transgender Population." Washington, D.C.: U.S. Bureau of Labor Statistics. Available at: https://www.bls.gov/osmr/research-papers/2017/pdf/st170200.pdf (accessed September 2019).

Human Rights Campaign. 2018. "Violence Against the Transgender Community in 2018." Human Rights Campaign. Available at: http://www.hrc.org/resources/violenceagainst-the-transgender-community-in-2018/ (accessed May 2019).

Institute of Medicine (US) Committee on Lesbian, Gay, Bisexual, Transgender Health Issues and Research Gaps and Opportunities. 2011. The Health of Lesbian, Gay, Bisexual and Transgender People: Building a Foundation for Better Understanding. Washington D.C.: The National Academies Press. DOI: https://doi.org/10.17226/13128.

Kreuter, F. and K. Olson. 2013. "Paradata for Nonresponse Error Investigation." In Improving Surveys with Paradata: Analytic Uses of Process Information, edited by F. Kreuter, 11-42. New York: Wiley and Sons.

Law, T. 2019. "Trump Administration Asks Supreme Court to Permit Employment Discrimination Against Transgender Workers." Time Magazine, August 17, 2019. Available at: https://time.com/5654844/title-vii-trump-transgender-department-of-justice-supreme-court/ (accessed September 2019).

Lee, S., K.I. Fredriksen-Golden, and C. McClain. 2018. "Are Sexual Minorities Less Likely to Participate in Surveys? An Examination of Proxy Nonresponse Measures and Associated Biases with Sexual Orientation in the Population-based Health Survey." Field Methods 30(3): 208-224. DOI: https://doi.org/10.1177/ $1525822 \mathrm{X} 18777736$.

Lin, I. and N.C. Schaeffer. 1995. "Using Survey Participants to Estimate the Impact of Nonparticipation.” The Public Opinion Quarterly 59(2): 236-258. DOI: https://doi.org/ $10.1086 / 269471$.

Masci, D., A. Brown, and J. Kiley. 2017. "5 Facts about Same-Sex Marriage.” Pew Research Center. Available at: https:/www.pewresearch.org/fact-tank/2017/06/26/ same-sex-marriage/ (accessed September 2019).

Massey, D.S. 2014. "Challenges to surveying immigrants." In Hard-to-Survey Populations, edited by R. Tourangeau, B. Edwards, T.P. Johnson, K.M. Wolter, and N. Bates, 270-292. Cambridge: Cambridge University Press. 
Masterpiece Cakeshop, Ltd. versus Colorado Civil Rights Commission. 2018. 584 U.S. Available at: https://www.supremecourt.gov/opinions/17pdf/16-111_j4el.pdf (accessed September 2019).

McGeeney, K., B. Kriz, S. Mullenax, L. Kail, G. Walejko, M. Vines, N. Bates, and Y. García. 2019. “2020 Census Barriers, Attitudes, and Motivators Study Survey Report." Suitland, MD: U.S. Census Bureau. Available at: https://www.census.gov/ programs-surveys/decennial-census/2020-census/planning-management/final-analysis/2020-report-cbams-study-survey.html (accessed May 2019).

Meiklejohn, J., J. Connor, and K. Kypri. 2012. "The Effect of Low Survey Response Rates on Estimates of Alcohol Consumption in a General Population Survey." PloS One 7(4): e35527. DOI: https://doi.org/10.1371/journal.pone.0035527.

Moohn, B. 2012. “2010 Census Integrated Communications Program Regional Partnership Assessment Report. 2010 Census Planning Memorandum Series, No. 217." Washington, D.C.: U.S. Census Bureau. Available at: https://www2.census.gov/programs-surveys/decennial/2010/program-management/5-review/cpex/2010memo-217.pdf?\# (accessed September 2019).

NHIS (National Health Interview Survey). 2015. "Sexual Orientation and Health among U.S. Adults: National Health Intervuew Survey." Hyatsville, MD: CDC/National Center for Health Statistics. Available at: https://www.cdc.gov/nchs/nhis/sexual_orientation/ statistics.htm (accessed September 2019).

NORC. 2014. "Same-Sex Marriage and Gay Rights: A Shift in Americans' Attitudes." The Associated Press-NORC Center for Public Affairs Research. Available at: http://www. apnorc.org/projects/Pages/HTML\%20Reports/same-sex-marriage-and-gay-rights-ashift-in-americans-attitudes0305-8272.aspx (accessed May 2019).

OECD. 2019. "Society at a Glance 2019: OECD Social Indicators". Paris, France: OECD Publishing. DOI: https://doi.org/10.1787/soc_glance-2019-en.

Rossi, P.H., J.D. Wright, G.A. Fisher, and G. Willis. 1987. "The urban homeless: estimating composition and size." Science 235(4794): 1336-1341. DOI: https://doi.org/10.1126/science.2950592.

Saewyc, E.M. 2011. "Research on Adolescent Sexual Orientation: Development, Health Disparities, Stigma and Resilience." Journal of Research on Adolescence 21(1): 256-272. DOI: https://doi.org/10.1111/j.1532-7795.2010.00727.x.

Schwede, L., R. Terry, and J.H. Childs. 2014. "Ethnographic evaluations on coverage of hard-to-count minorities in the US decennial census." In Hard-to-Survey Populations, edited by R. Tourangeau, B. Edwards, T.P. Johnson, K.M. Wolter, and N. Bates, 293-315. Cambridge: Cambridge University Press.

Stoop, I.A.L. 2005. The Hunt for the Last Respondent. The Hague, the Netherlands: Social and Cultural Planning Office (SCP).

U.S. Census Bureau. 2013. "U.S. Census Bureau Statistical Quality Standards." Suitland, MD.: U.S. Census Bureau. Available at: https://www.census.gov/content/dam/Census/ about/about-the-bureau/policies_and_notices/quality/statistical-quality-standards/Quality_Standards.pdf (accessed September 2019).

U.S. Census Bureau. 2016. National Advisory Committee on Race, Ethnic and Other Populations. "Administrative Records, Internet, and Hard to Count Population Working Group: Final Report." Suitland, MD.: U.S. Census Bureau. Available at: 
https://www2.census.gov/cac/nac/reports/2016-07-admin_internet-wg-report.pdf (accessed September 2019).

Williams, D. and M. Brick. 2018. "Trends in US Face-to-Face Household Survey Nonresponse and Level of Effort." Journal of Survey Statistics and Methodology 6(2): 186-211. DOI: https://doi.org/10.1093/jssam/smx019.

Zauzmer, J. and T. McCoy. 2019. "D.C. Hate Crimes Nearly Double since 2016, with LGBTQ Community the Biggest Target." Washington Post, February 2, 2019. Available at: https://www.washingtonpost.com/local/social-issues/hate-crimes-in-dchave-nearly-doubled-since-2016-according-to-city-data-and-incidents-based-on-sexual-orientation-top-the-list/2019/02/02/967aa46a-2651-11e9-90cd-dedb0c92dc17_ story.html (accessed September 2019).

Received May 2019

Revised September 2019

Accepted November 2019 